\title{
A systematic review of the epidemiology of hepatitis E virus in Africa
}

\author{
Jong-Hoon Kim', Kenrad E Nelson², Ursula Panzner', Yogita Kasture, Alain B Labrique ${ }^{2}$ and Thomas F Wierzba ${ }^{1 *}$
}

\begin{abstract}
Background: Hepatitis E Virus (HEV) infection is a newly recognized serious threat to global public health and Africa is suspected to be among the most severely affected regions in the world. Understanding HEV epidemiology in Africa will expedite the implementation of evidence-based control policies aimed at preventing the spread of HEV including policies for the use of available resources such as HEV vaccines.

Methods: Here we present a comprehensive review of HEV epidemiology in Africa based on published data. We searched for articles on HEV epidemiology in Africa from online databases such as PubMed, Scopus, and ISI Web of Science and critically reviewed appropriate publications to extract consistent findings, identify knowledge gaps, and suggest future studies.

Results: Taking a particularly high toll in pregnant women and their fetuses, HEV has infected human populations in 28 of 56 African countries. Since 1979, 17 HEV outbreaks have been reported about once every other year from Africa causing a reported 35,300 cases with 650 deaths.

Conclusions: In Africa, HEV infection is not new, is widespread, and the number of reported outbreaks are likely a significant underestimate. The authors suggest that this is a continent-wide public health problem that deserves the attention of local, regional and international agencies to implement control policies that can save numerous lives, especially those of pregnant women and their fetuses.
\end{abstract}

Keywords: Hepatitis E, Africa, Review, Outbreak, Pregnancy

\section{Background}

Hepatitis E virus (HEV) causes large outbreaks and sporadic cases of acute hepatitis, and an estimated one-third of the world's population has been infected with HEV [1]. It is the most or second most common cause of acute viral hepatitis among adults throughout much of Asia, the Middle East, and Africa [2-4] although the true burden of HEV infection remains unknown [1]. HEV infection is usually self-limiting, but may develop into fulminant hepatitis with a case-fatality rate (CFR) between 1 and $2 \%$ in the general population [5], which can rise to over $40 \%$ in pregnant women, especially during the third trimester of pregnancy [6].

HEV was first identified in 1983 during the search for the causative agent of an outbreak of enterically transmitted non-A, non-B (NANB) hepatitis [7]. Its full-length

\footnotetext{
* Correspondence: twierzba@ivi.int

'International Vaccine Institute, SNU Research Park, San 4-8,

Nakseongdae-dong, Gwanak-gu, Seoul 151-919, South Korea

Full list of author information is available at the end of the article
}

genome was first cloned in 1991 [8]. It is a spherical, nonenveloped, single-stranded RNA virus belonging to the Hepeviridae family and the Hepevirus genus [9]. The existing evidence suggests all human HEV strains belong to a single serotype [10] although there are at least four genotypes (1-4) $[11,12]$ with 24 subtypes $[3,12,13]$. Genotypes 1 and 2 are predominantly found in populations in developing countries whereas genotypes 3 and 4 are zoonotic and globally distributed [3]. Two recombinant HEV vaccine candidates have been clinically evaluated [14-16]. One vaccine candidate, $\mathrm{rHEV}$, showed $95.5 \%$ efficacy after three doses in phase II trial in Nepalese military population while the other vaccine, HEV 239, showed 100\% efficacy after three doses in phase III trial in a Chinese population. HEV 239 is licensed by China's Ministry of Science and Technology [17], and is being produced and marketed by Xiamen Innovax Limited [18].

The first retrospectively (serologically) confirmed HEV outbreak occurred in New Delhi, India in 1955-56 with 
more than 29,000 symptomatic jaundiced persons [19-21]. Since then, many serologically confirmed outbreaks and sporadic cases [3,22] and probable outbreaks have occurred, especially in Asia and Africa [23]. Africa has usually been the place where resources for controlling infectious diseases are last deployed although it is among the regions most severely inflicted by infectious diseases [24]. Acknowledging that understanding $\mathrm{HEV}$ infection and distribution in Africa can expedite implementation of evidence-based control policies, our overall objective was to characterize the epidemiology of HEV in Africa by reviewing and summarizing relevant, peer-reviewed literature. The authors' specific objectives were to explore rates of infection (i.e., seroprevalence, outbreaks, sporadic cases), severity (i.e., case-fatality rates), modes of transmission, and circulating genotypes. The authors also identified knowledge gaps in the existing literature and suggested future studies.

\section{Methods}

\section{Searching}

We searched PubMed, Scopus, and ISI Web of Science (up to March 24, 2014) using the following search terms: ("Hepatitis E" OR "Non A Non B") AND (Country_ name_1 OR Country_name_2 OR ...), where ellipsis represents names of all African countries (with OR between them) as extracted from a UN list [25]. The search term includes "Non A Non B" because HEV was identified as the causative agent of the enterically transmitted NANB hepatitis [7] and thus should be responsible for at least some of NANB outbreaks. In addition, we reviewed relevant references from the articles we obtained. Articles published in English and French were included.

\section{Selection and methods}

Figure 1 is a flow chart that describes the procedure of literature selection. We identified 219, 288, and 159 articles from PubMed, Scopus, and ISI Web of Science, respectively, and also reviewed articles obtained by screening references. The number of articles was 426 after removing duplicates. Of 426 articles, we synthesized 160 original research articles that provide relevant information while excluding the other 266 articles for the following reasons:

1. Non-African populations $(\mathrm{n}=28)$

2. Topics other than HEV epidemiology, e.g., molecular biology $(n=168)$

3. Insufficient information, e.g., case report $(n=34)$

4. Review articles $(n=25)$

5. Suboptimal methodology $(n=11)$

Of 160 articles, we summarized 138 articles about serologically confirmed HEV in the main text and separately summarized NANB outbreaks in the Additional file $1(n=22)$.

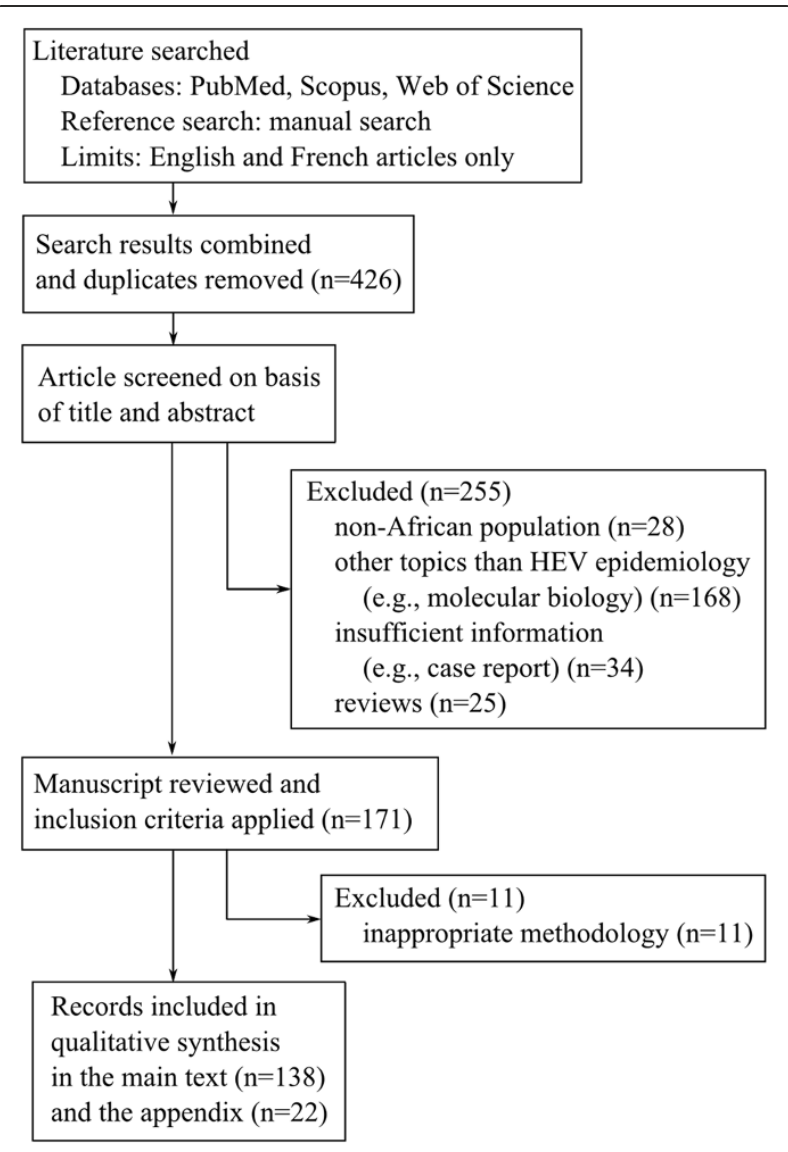

Figure 1 Flow diagram for study selection.

HEV seroprevalence analysis included articles describing serology studies for total antibodies (i.e., both IgG and IgM) or IgG to HEV by enzyme-linked immunosorbent assay, using commercial kits or in-house methods. In outbreaks, incident cases of HEV are defined by the existence of IgM antibodies to HEV or paired serum samples with a significant increase in IgG to HEV or the existence of HEV RNA measured by reverse transcriptase polymerase chain reaction. CFR was defined as the number of deaths divided by the number of laboratory confirmed cases or cases epidemiologically linked to HEV infections times 100.

\section{Data source}

Sources of data on the epidemiology of HEV come from (i) seroprevalence studies in the general population (e.g., blood donors or healthy population) or suspected high-risk population (e.g., pig handlers or waste water treatment plant workers or pregnant women), (ii) studies of sporadic acute hepatitis patients, and (iii) investigations of hepatitis outbreaks. We also discuss studies of sporadic cases and outbreaks of NANB hepatitis viruses in the Discussion Section with tables of data in the Additional file 1. The present paper includes studies from 28 (50\%) of 56 African countries: Algeria [26-28], Burkina Faso [29], Burundi [30,31], 
Cameroon [32], Central African Republic [33,34], Chad [27,28,35-38], Côte d'Ivoire [39], Democratic Republic of the Congo [40], Djibouti [41,42], Ethiopia [6,43], Eritrea [44], Egypt [45-71], Gabon [72,73], Ghana [32,74-78], Kenya [79,80], Madagascar [81], Mayotte [82], Morocco [83-85], Namibia [86-88], Nigeria [89-91], Senegal [92,93], Somalia [94-96], South Africa [97,98], South Sudan [99], Sudan [35,100-105], Tunisia [106-111], the United Republic of Tanzania [112-114], and Zambia [115].

\section{Results}

\section{Seroprevalence of anti-HEV antibodies}

Data on seroprevalence of anti-HEV antibodies comes from 35 studies in 13 African countries. Table 1 presents a summary sorted by country name and seroprevalence. Seroprevalence varies by country from $84.3 \%$ [55] among pregnant Egyptian women aged 24 years on average to $0 \%$ among village residents aged 24 years on average in Gabon [72]. The seroprevalence seems to be higher in pregnant women than in the general population in Ghana (28.7\% [78] vs. 4.6\% [76]) and also in Gabon (14.2\% [73] vs. $0 \%$ [72]). Two studies of Ghanaians suggest that predominant HEV genotypes in that country may be of zoonotic origin: seroprevalence among pig handlers is over 34\% [75,77] whereas that among general population is about 4\% [76]. Seroprevalence also differs between rural and urban areas. In Gabon, one study found a higher prevalence of HEV of about 2.0 times in urban (13.5\%) compared with rural areas (6.4\%) [73]. On the other hand, in South Africa, HEV seroprevalence is higher in rural compared with urban residents (15.3\% vs. 6.6\%) [98]. The difference in seroprevalence between rural and urban residents is also observed in Egypt with seroprevalence being higher in rural areas [53].

\section{Sporadic hepatitis cases attributed to HEV}

Data on acute hepatitis E come from studies of sporadic acute hepatitis cases and are available from 29 studies in 13 African countries. Table 2 shows a summary sorted by country followed by decreasing proportion of sporadic hepatitis cases that are attributable to HEV infection. Table 2 also provides characteristics of sporadic hepatitis cases studied and types of antibodies tested (i.e., IgG or IgM). The proportion of cases that are attributable to HEV ranges from $70 \%$ in male patients aged $25-33$ years in Nigeria [89] to $2 \%$ in patients aged $<15$ years in Egypt [48]. It is interesting to note that existing studies show that the proportions of cases that are attributable to HEV are lower than $27 \%$ in Egypt despite their high HEV seroprevalence: the majority of acute hepatitis patients were attributable to $\mathrm{HAV}[45,48,64,70]$ or HBV [71]. For example, one study of acute hepatitis among Egyptian children with a mean age of 5.4 years reported that HAV was responsible for 35 out of 36 acute hepatitis cases whereas HEV was detected in only one case [48].

\section{Outbreaks and attack rate}

The first well-characterized outbreak of laboratoryconfirmed Hepatitis E occurred in Côte d'Ivoire in 1986 [39]. However, assuming that hepatitis outbreaks characterized by acute jaundice and a high CFR among pregnant women were likely due to HEV, Teo identified earlier, probable HEV outbreaks in Tunisia from 1950 to 1953, Algeria from 1952 to 1956, Congo in 1958, Morocco from 1958 to 60, and Libya from 1968 to 1970 and also in 1975 [23].

HEV outbreaks have been detected in 11 African countries (17 studies), of which some outbreaks in refugee camps $[79,86,100]$ and Table 3 presents a summary of these outbreaks sorted by country name and decreasing clinical attack rate. The highest attack rate (25.1\%) of the population was observed during outbreaks in two subcounties of Kitgum District, Uganda from October 2007 to June 2009 [119,120]. Attack rate could have been even higher because the epidemic had not ended at the time of the investigation and in particular, it had not even peaked but was increasing in one of two subcounties. The lowest attack rate $(2.7 \%)$ was observed during an outbreak in the Central African Republic on July 2002 [34].

Published reports suggest clinical HEV infection risk is highest among young adults in African populations $[44,79,86,94,100,119,120]$ although one study reports no significant difference in the risk of clinical HEV infection by age [34]. Studies show mixed results regarding whether sex predisposes people to clinical HEV infection (i.e., higher risk for males [86] or higher risk for females $[119,120]$ or no significant difference $[34,79,94,100,123]$.

\section{Case fatality rate (CFR)}

The CFR from outbreak investigations or sporadic cases were reported by 8 African countries (10 studies). Table 4 presents a summary sorted by CFR and pregnancy. CFR's in the overall population range from $17.8 \%$ in Darfur, Sudan in 2004 [101] to $1.5 \%$ in Uganda during March to December, 2008 [123]. Among pregnant women, fatalities are considerably higher ranging from $42.1 \%$ among sporadic cases sampled during 1988-91in Ethiopia [6] to $12.5 \%$ during an outbreak in Dadaab refugee camp of Kenya in 2012 [80]. Compared with the overall population, fatalities are also higher in children under 2 years of age. One study in Uganda using active case detection and verbal autopsies found that icteric children less than two years of age experienced $13 \%$ mortality, which was higher than the $6.9 \%$ experienced among pregnant woman [120]. One author claims that the inoculum size may be important in determining CFR: CFR was $8.6 \%$ among villagers supplied by wells whereas it was $2.5 \%$ and $0.8 \%$ in those relying on river and pond water, respectively [94]. 
Table 1 Seroprevalence of anti-HEV antibodies in Africa

\begin{tabular}{|c|c|c|c|c|c|c|}
\hline Country & \% sero-prevalence & Sample demographics & $\begin{array}{l}\text { Sample } \\
\text { size }\end{array}$ & $\begin{array}{c}\text { Year of } \\
\text { sampling }\end{array}$ & $\begin{array}{l}\text { Diagnostic } \\
\text { methods }\end{array}$ & Source \\
\hline \multirow[t]{2}{*}{ Burkina Faso } & 19.1 & Blood donors & 178 & $2010-12$ & $\lg G$ & [29] \\
\hline & 11.6 & Pregnant women & 189 & 2010-12 & $\lg G$ & [29] \\
\hline Burundi & 14.0 & Adults without chronic liver disease, 44.7 yrs old $( \pm 13.5)$ & 129 & 1986 & Total lg & [30] \\
\hline \multirow[t]{2}{*}{ Cameroon } & 14.2 & HIV-infected adults, 38.1 yrs old $( \pm 11.3)$ & 289 & 2009-10 & $\lg G$ & {$[32]$} \\
\hline & 2.0 & HIV-infected children, 8.3 yrs old ( \pm 7.5 ) & 100 & 2009-10 & $\lg G$ & [32] \\
\hline CAR $^{\mathrm{a}}$ & 24.2 & Patients attending the center for sexually transmitted diseases & 157 & $1995^{b}$ & Total lg & [33] \\
\hline Djibouti & 13.0 & Male peacekeepers in Haiti, 31.2 yrs old & 112 & $1998^{b}$ & Total lg & [42] \\
\hline \multirow[t]{13}{*}{ Egypt } & 84.3 & Pregnant women, 24 yrs old (16-48) & 2,428 & 1997-2003 & Total lg & [55] \\
\hline & 80.1 & Patients with chronic liver disease, 48 yrs old (23-62) & 518 & $2000-2$ & $\lg G$ & [57] \\
\hline & 67.6 & Residents of two rural villages, 24.5 and $26.5 \mathrm{yrs}$, respectively & 10,156 & 1997 & Total lg & [54] \\
\hline & 58.6 & Pregnant women, $\sim 33$ yrs old & 116 & 2009 & $\lg G$ & [58] \\
\hline & 56.4 & Residents of a semi-urban village, 1-67 yrs old & 140 & 1993 & Total lg & [51] \\
\hline & 51.2 & Waste water treatment plant workers, 47.1 yrs old & 43 & $2011^{\mathrm{b}}$ & Total lg & {$[60]$} \\
\hline & 50.6 & Waste water treatment plant workers, 20-60 yrs old & 233 & $2000^{b}$ & Total lg & [61] \\
\hline & 45.3 & Blood donors, $18-45$ yrs old & 95 & $1998^{\mathrm{b}}$ & $\lg G$ & [52] \\
\hline & 54.1 & Four waste water treatment plant male workers, $20-60$ yrs old & 205 & 1998-9 & $\lg G$ & [116] \\
\hline & 39.6 & Haemodialysis patients, 8-20 yrs old & 96 & $1998^{b}$ & $\lg G$ & [52] \\
\hline & 38.9 & Healthy females, 21.8 yrs old (16-25) & 95 & 1995 & $\lg G$ & [50] \\
\hline & 17.2 & Residents of a hamlet, 20.9 yrs old $(<1-95)$ & 1259 & 1992 & $\lg G$ & [49] \\
\hline & 0.0 & Healthy controls, 20-60 yrs old & 96 & 1998-9 & $\lg G$ & [116] \\
\hline \multirow[t]{2}{*}{ Gabon } & 14.2 & Pregnant women, 24.6 yrs old (14-44) & 840 & 2005,2007 & $\lg G$ & [73] \\
\hline & 0.0 & Villagers, 29 yrs old (2-80) & 35 & $1991-2$ & Total lg & [72] \\
\hline \multirow[t]{6}{*}{ Ghana } & 45.3 & Adult HIV patients ( $n=402), 40$ yrs old $( \pm 9.6)$ & 402 & $2008-10$ & $\lg G$ & [32] \\
\hline & 38.1 & Pig handlers, 36.5 yrs old (12-65) & 105 & $2009^{b}$ & Total lg & [77] \\
\hline & 34.8 & Pig handlers, 32.9 yrs old (15-70) & 353 & 2008 & Total lg & [75] \\
\hline & 28.7 & Pregnant women, 28.9 yrs old (13-42) & 157 & 2008 & Total lg & [78] \\
\hline & 4.6 & Blood donors & 239 & $2012^{\mathrm{b}}$ & $\lg G$ & [76] \\
\hline & 4.4 & $6-18$ yr olds & 803 & 1993 & Total lg & [74] \\
\hline Madagascar & 14.1 & Slaughterhouse workers & 427 & $2008-9$ & Total lg & [81] \\
\hline \multirow[t]{2}{*}{ Morocco } & 8.5 & Blood donors & 200 & $2000-1$ & $\lg G$ & {$[85]$} \\
\hline & 2.2 & 232 men and 259 women, 27.7 yrs old $( \pm 5.9)$ & 491 & $1995^{b}$ & $\lg G$ & {$[84]$} \\
\hline \multirow[t]{3}{*}{ Nigeria } & 43.0 & Health care workers & 88 & 2008-9 & Total lg & {$[90]$} \\
\hline & 94.0 & Control healthy adults & 44 & 2008-9 & Total lg & [90] \\
\hline & 13.4 & Healthy and sick people, 29.8 yrs old (3-72) & 186 & 2007 & Total lg & [91] \\
\hline \multirow[t]{3}{*}{ South Africa } & 10.7 & Urban $(n=407)$ and rural $(n=360)$ blacks, 42.4 yrs old $(18-85)$ & 767 & $1996^{\mathrm{b}}$ & Total lg & {$[98,117]$} \\
\hline & 2.6 & Medical students & 227 & 1992 & Total lg & [97] \\
\hline & 1.8 & Canoeists who have been regularly exposed to waste water & 555 & 1992 & Total lg & [97] \\
\hline \multirow[t]{3}{*}{ Tanzania } & 6.6 & Women, 32.1 yrs old (15-45) & 212 & 1996 & Total lg & [114] \\
\hline & 0.2 & Healthy adults, 30.3 yrs old & 403 & 1992 & Total lg & [112] \\
\hline & 0.0 & Women, 24.5 yrs old & 180 & 1995 & Total lg & [113] \\
\hline \multirow[t]{3}{*}{ Tunisia } & 46.0 & Healthy persons, $>60$ yrs old & 100 & 1991 & $\lg G$ & [106] \\
\hline & 29.5 & Children with chronic haematological diseases & 34 & 1996 & $\lg G$ & [106] \\
\hline & 28.9 & $\begin{array}{l}\text { Polytransfused patients; adults }(n=59,34.8 \text { yrs old }(20-61)) \\
\text { and children }(n=48,7.3 \text { yrs old }(1-15))\end{array}$ & 107 & $2008-9$ & $\lg G$ & [107] \\
\hline
\end{tabular}


Table 1 Seroprevalence of anti-HEV antibodies in Africa (Continued)

\begin{tabular}{|c|c|c|c|c|c|c|}
\hline & 22.0 & Healthy blood donors, < 40 yrs old & 100 & 1996 & $\lg G$ & [106] \\
\hline & 12.1 & Pregnant women, 30.1 yrs old (17-52) & 404 & $2008-9$ & $\lg G$ & [108] \\
\hline & 10.0 & $\begin{array}{l}\text { Healthy controls; blood donors }(n=100,31.3 \text { yrs old }(20-58)) \\
\text { and children, }(n=60,7.9 \text { yrs old }(1-15))\end{array}$ & 160 & $2008-9$ & $\lg G$ & {$[107]$} \\
\hline & 5.4 & Blood donors, 32.6 yrs old $( \pm 8.6)$ & 687 & $2007-8$ & Total lg & {$[109]$} \\
\hline & 4.3 & Healthy persons, 20.7 yrs old (16-25) & 1,505 & $2008^{b}$ & $\lg G$ & {$[110]$} \\
\hline \multirow[t]{2}{*}{ Zambia } & 42 & Urban adults, 18-64 yrs old & 106 & 1999 & $\lg G$ & {$[115]$} \\
\hline & 16 & Urban children, 1-15 yrs old & 194 & 2011 & $\lg G$ & {$[115]$} \\
\hline
\end{tabular}

${ }^{a}$ CAR; Central African Republic.

${ }^{\mathrm{b}}$ The year of the publication.

Seroprevalence varies by country and by subpopulation and studies were done under different conditions (e.g., sample size, demographics, and different diagnostic methods). Age of the sample is provided as mean (range or \pm standard deviation, if available).

\section{Genotype prevalence}

Data on the genotypes of circulating HEV's are available for 9 countries (16 studies). Table 5 presents a summary sorted by genotype and also provides characteristics of the sample, genomic regions tested. Genotype 1 seems to be most prevalent as it was found in Central African Republic [34], Sudan [35], Chad [28,35], Egypt [46,62,124], and Namibia [88] followed by genotype 2, which were observed in Central African Republic [34], Chad [35], Namibia [87], and Nigeria [6,89]. Genotype 3 is rare and was found in one Egyptian child [48], one acute hepatitis patient in Mayotte (originally from France) [82]. Genotype prevalence can differ in neighboring countries as was demonstrated by one study in Sudan and Chad where genotype 1 was more common in Sudan and genotype 2 was more common in Chad [35], Figure 2 shows a map of Africa where countries in which HEV infections were observed are differently colored according to HEV genotype.

\section{Mode of transmission}

Studies stress the importance of fecal contamination of water as a main source of infection in outbreaks across African countries [34,44,86,94,100,101,123]. However, in a laboratory-confirmed HEV outbreak of 3,218 cases in northern Uganda, the authors suggest that some patients were infected through person-to-person transmission, which is supported by three observations: (1) HEV was not detected from water or zoonotic sources, (2) the epidemic curve suggested a propagated, not point-source outbreak, and (3) there was evidence of close contact between incident cases and subsequently infected household contacts after an incubation period [120]. Non-human reservoirs have been identified in donkeys in Sudan (unknown genotype) [100] and pigs the Democratic Republic of the Congo and Uganda (both genotype 3), and cows, buffaloes, sheep and goats in Egypt [40,120]. In Ghana, the high prevalence (34.8\%) of antibodies to HEV in pig farm workers was reported with the greatest risk factor being close contact with piped-water [75,77]. No data have been reported from Africa suggesting the transmission of
HEV by transfusion or by sexual intercourse [125] although the transmission of HEV by transfusion has been well documented in Europe and Japan [126,127]. A single Egyptian study suggested HEV transmission from mothers to their neonates. Of nine mothers PCR positive for HEV RNA, five (55.6\%) of their neonates were also PCR positive [128]. No other studies have investigated mother-to-child transmission in Africa.

\section{Co-infection with other infectious diseases}

Three infectious diseases-hepatitis viruses other than HEV, schistosomiasis, and HIV-are known to be associated with an increased risk or severity of HEV infection from published studies. First, infection with other hepatitis viruses was positively associated with infection with HEV. One study found a high prevalence of anti-HEV antibodies in Egyptian children infected with Hepatitis B (56.7\%), Hepatitis C (52\%) and both Hepatitis B and C (30\%) compared with patients with non-A, non-B, non-C hepatitis (7.1\%) [129]. Second, one study showed that patients with schistosomiasis infection had a higher prevalence of $\mathrm{HEV}$ infection: seroprevalence of HEV infection was 31\% in patients with Schistosoma mansoni whereas it was $14 \%$ among parasite-free individuals [53]. Third, studies reported discordant findings as to whether patients with HIV infection or AIDS are at increased risk for HEV infection. One study reported that anti-HEV seroprevalence among HIV/AIDS cases in Africa was similar to HIV negatives and concluded that there is no significant increased risk for HEV infection in patients with HIV positive [30]. Another study showed the seroprevalence of anti-HEV IgG antibodies was higher among HIV-1 infected women than HTLV-I infected women (7.1\% vs. 5.0\%) [130]. Similarly, HEV infection was significantly more common in HIV-seropositive than HIV-seronegative Zambian adults (odds ratio $=6.2,95 \% \mathrm{CI}, 2.2-17.8$ ). [115]

\section{Discussion}

The first documented outbreak of HEV infection likely occurred in 1950 in Tunisia [23] and since the 1980's, when 
Table 2 Sporadic cases caused by hepatitis E virus in Africa

\begin{tabular}{|c|c|c|c|c|c|c|}
\hline Country & $\%$ sero-positivity & Case demographics & $\begin{array}{l}\text { No. of } \\
\text { cases }\end{array}$ & $\begin{array}{l}\text { Year of } \\
\text { sampling }\end{array}$ & $\begin{array}{l}\text { Diagnostic } \\
\text { methods }\end{array}$ & Source \\
\hline \multirow[t]{2}{*}{ Chad } & 48.8 & Acute or fulminant hepatitis patients, 4-64 yrs old & 41 & 1993 & $\lg M$ & {$[36]$} \\
\hline & $20.0^{\mathrm{a}}$ & Sporadic cases & 17 & 1994 & RT-PCR ${ }^{b}$ & [27] \\
\hline Djibouti & 58.5 & Acute hepatitis patients, $21 \cdot 8$ yrs old (2-65) & 65 & $1992-3$ & $\lg M$ & [41] \\
\hline \multirow[t]{13}{*}{ Egypt } & 21.7 & Acute hepatitis patients, $26 \cdot 6$ yrs old (18-60) & 143 & 1993-4 & $\lg M$ & [71] \\
\hline & 24.2 & Jaundiced patients, 1-73 yrs old & 202 & 1993 & $\lg M$ & [46] \\
\hline & 22.2 & Jaundiced children, 5 yrs old (1-11) & 261 & 1990 & $\lg M$ & [70] \\
\hline & 20.2 & Acute viral hepatitis patients, 8 yrs old & 287 & 2006-8 & $\lg M$ & {$[62]$} \\
\hline & 17.9 & Acute hepatitis patients, 15.7 ( \pm 14.9$)$ yrs old & 235 & $2007-8$ & $\begin{array}{l}\lg M \text { or }>=3 \text {-fold rise in } \\
\lg G\end{array}$ & [69] \\
\hline & 17.2 & $\begin{array}{l}\text { Children with elevated level (two-fold or more) of AST and } \\
\text { ALT }\end{array}$ & 64 & $2006^{d}$ & $\lg M$ & [47] \\
\hline & 15.7 & Acute hepatitis patients, 15.9 yrs old (1-65) & 235 & $2007-8$ & $\lg M$ & [63] \\
\hline & 15.1 & Children with acute jaundice, $6 \cdot 4$ yrs old (1-13) & 73 & $1987-8$ & $\lg M$ & [45] \\
\hline & 12.5 & Patients with acute hepatitis, $20 \cdot 2$ yrs old (4-65) & 200 & $2001-2$ & $\lg M$ & [64] \\
\hline & 6.0 & Children with minor hepatic ailments, 6 mo -10 yrs & 100 & 2004-5 & $\lg M$ & [65] \\
\hline & $5 \cdot 0$ & Patients with acute on chronic liver failure, 46.4 yrs old & 100 & 2009-10 & $\lg M$ & [66] \\
\hline & 2.1 & Acute viral hepatitis patients, 25 yrs old (2-77) & 47 & $2002-5$ & $\lg M$ & [67] \\
\hline & 2.0 & Hepatitis patients, 5.4 yrs old (1.5-15) & 50 & 2007 & RT-PCR & [48] \\
\hline \multirow[t]{3}{*}{ Ethiopia } & 45.6 & Acute viral hepatitis patients with NANB & 79 & 1988-91 & $\mathrm{FABA}^{\mathrm{d}}$ & [43] \\
\hline & 31.8 & Non-pregnant women with acute viral hepatitis, 30 yrs old & 22 & 1988-91 & FABA & [6] \\
\hline & $67 \cdot 9$ & Pregnant women with acute viral hepatitis, 26 yrs old & 28 & 1988-91 & FABA & [6] \\
\hline Mayotte & 100.0 & Patients with acute jaundice, 46 yrs old & 1 & 2009 & $\lg M$ & [82] \\
\hline Nigeria & 70.0 & Male patients with acute hepatitis, 25-33 yrs old & 10 & $1997-8$ & RT-PCR & [89] \\
\hline \multirow[t]{2}{*}{ Senegal } & 20.0 & Patients with jaundice & 30 & $1992^{c}$ & $\lg M$ & [93] \\
\hline & 10.2 & Patients with viral hepatitis & 49 & $1993^{c}$ & $\lg M$ & [92] \\
\hline Somalia & 61.1 & $\begin{array}{l}\text { Native Somalis and displaced Ethiopian patients } \\
\text { with acute hepatitis, 7-90 yrs old }\end{array}$ & 36 & $1992-3$ & $\lg M$ & [96] \\
\hline \multirow[t]{2}{*}{ Sudan } & 5.4 & Patients with fulminant hepatic failure, 38 yrs old (19-75) & 37 & $2003-4$ & $\lg M$ & [103] \\
\hline & 59.0 & Children with acute clinical jaundice, $\leq 14$ yrs old & 39 & $1987-8$ & $\lg M$ & [118] \\
\hline
\end{tabular}

${ }^{a} 20 \%$ was extrapolated from the results of RT-PCR results of 5 samples out of total 17 cases.

${ }^{\mathrm{b}}$ Reverse transcription polymerase chain reaction.

'The year of the publication.

${ }^{d}$ FABA; fluorescent antibody blocking assay, which is claimed to detect acute infection, not but past infection.

Proportion of sporadic hepatitis cases attributable to HEV varies by country and by subpopulation and studies were done under different conditions (e.g., sample size, demographics, and different diagnostic methods). Age of the sample is provided as mean (range or \pm standard deviation, if available).

HEV diagnostic assays became available, half of all African countries including nations in north, south, east, west, and central Africa have published articles of Hepatitis E infections. Clearly, these results suggest that HEV infection is not new to Africa and implies that this is a continent-wide public health problem and a potential threat to travelers. This is supported by a recently published study on HEV in low- and middle-income countries in Asia and Africa [131]. HEV infection deserves the attention of local, regional and international agencies.

Since nations lack routine surveillance for HEV infection, it is difficult to estimate the African disease burden.
However, these publications suggest that outbreaks are frequent with about one outbreak report published every other year from Africa. As only a few outbreaks are likely identified and even fewer reported in peer-reviewed journals, it is probable that outbreaks in Africa are even more common than these reports imply. To address HEV outbreak control, routine HEV surveillance and response is necessary and could be integrated with measles or poliomyelitis surveillance, which are ongoing activities in most countries.

Among HEV outbreaks, the overall case-fatality rate is comparable to that seen with other diseases such as cholera 
Table 3 Hepatitis E outbreaks in Africa

\begin{tabular}{|c|c|c|c|c|c|c|}
\hline \multirow[t]{2}{*}{ Country } & \multirow[t]{2}{*}{ Year } & \multirow{2}{*}{$\begin{array}{l}\text { No. cases } \\
\text { (deaths) }\end{array}$} & \multirow{2}{*}{$\begin{array}{l}\text { Clinical attack rate } \\
\text { (population size) }\end{array}$} & \multicolumn{2}{|c|}{ Variance in clinical attack rates } & \multirow[t]{2}{*}{ Source } \\
\hline & & & & By age & By gender & \\
\hline Algeria & $1979-80$ & 20 & $N A^{a}$ & NA & NA & [27] \\
\hline \multirow[t]{2}{*}{$C A R^{b}$} & Jul - Oct 2002 & 715 & $2.7 \%$ & No significant difference & No significant difference & [34] \\
\hline & Jun 2004 - Sep 2005 & 411 & NA & $\begin{array}{l}\text { The age group } 18-34 \text { years was more frequently } \\
\text { anti-HEV IgM positive }(91.2 \%) \text { than those aged } \\
1-17(78.0 \%) \text { or over } 34(64.9 \%)(p<0.001)\end{array}$ & $\begin{array}{l}\text { Risk for infection was clearly higher in males } \\
\text { than females based on lgG seroprevalence } \\
\text { (OR }=2.04 ; 95 \% \mathrm{Cl} 1.21-3.45 ; p<0.005)\end{array}$ & [121] \\
\hline \multirow[t]{2}{*}{ Chad } & $1983-4$ & 34 & NA & NA & NA & {$[27]$} \\
\hline & Jun - Aug 2004 & $989(30)$ & NA & NA & NA & {$[37,38]$} \\
\hline Djibouti & Dec1992-Sep1993 & 43 & NA & NA & NA & [41] \\
\hline Eritrea & Oct 1988-Mar 1989 & $>750$ & NA & $\begin{array}{l}81 \% \text { of the patients were between } 18 \text { and } \\
30 \text { years of age among aged from } 15 \text { to } 56 .\end{array}$ & $\begin{array}{l}\text { The outbreak among military personnel; } \\
\text { no female patients }\end{array}$ & [44] \\
\hline \multirow[t]{2}{*}{ Kenya $^{d}$} & Mar - Oct 1991 & $1,765(63)$ & $6.3 \%(n=26,920)$ & $\begin{array}{l}\text { Increased with age with a peak among those }>30 \text {, } \\
\text { while serologic attack rate is not different by age group }\end{array}$ & $\begin{array}{l}\text { Clinical attack rate is } 6.1 \% \text { for male } \\
\text { and } 6.3 \% \text { for female }\end{array}$ & [79] \\
\hline & Jul - Nov 2012 & $349(10)$ & NA & NA & $184(54.3 \%)$ were females. & {$[80]$} \\
\hline Morocco & 1994 & $>75$ & NA & NA & NA & [83] \\
\hline Namibia $^{d}$ & Jul - Oct 1983 & 201 & NA & $\begin{array}{l}\text { Most common in persons aged } 25-29 \text { years old } \\
\text { among patients aged } 5-54 \text { years old }\end{array}$ & $72 \%$ of 64 patients were male. & {$[86]$} \\
\hline Somalia & $1988-9,23$ months & $11,759(346)$ & $4.7 \%(n=245,312)$ & $\begin{array}{l}\text { Increased with age groups: } 5 \%, 13 \% \text {, and } 20 \% \text { for } \\
\text { those aged } 0-4,5-15 \text {, and }>15 \text { years old, respectively }\end{array}$ & Female-to-male ratio was $1.08: 1$ & {$[94,95]$} \\
\hline South Sudan & Jul 2012-Jan 2013 & 5,080 & $7.4 \%$ & Persons aged $18-59$ years had the highest attack rates & NA & [99] \\
\hline \multirow[t]{3}{*}{ Sudan } & Oct 1988 & $\geq 55$ & NA & NA & NA & [122] \\
\hline & Jul - Dec 2004 & $2,621(45)$ & $3.3 \%^{c, d}(n=78,800)$ & $\begin{array}{l}\text { Being } 15-45 \text { years old was a risk factor for } \\
\text { clinical } \mathrm{HEV} \text { infection with odds ratio being } \\
2.13(95 \% \mathrm{Cl}, 1.02-4.46) \text {. }\end{array}$ & No significant difference & {$[100]$} \\
\hline & Nov 2010-Mar 2011 & $39^{\mathrm{e}}\left(11^{\mathrm{e}}\right)$ & NA & NA & Only pregnant women were reported. & [104] \\
\hline Uganda & Oct 2007 -Jun 2009 & $>10,356(160)$ & $25.1 \%(n=19,098)$ & $<2$ year olds (6.9\%) vs. pregnant women (87\%) & $22 \%$ males vs. $28 \%$ females $(p<0.001)$ & {$[119,120,123]$} \\
\hline
\end{tabular}

${ }^{a} \mathrm{NA}$; not available.

${ }^{\mathrm{b}} \mathrm{CAR}$; Central African Republic.

CActive case finding suggested a clinical attack rate of $16 \%$

dOutbreak in refugee camps.

${ }^{\mathrm{e}}$ For pregnant women. 
Table 4 Case-fatality rates (CFRs) of HEV infection

\begin{tabular}{|c|c|c|c|c|}
\hline \multirow[t]{2}{*}{ Country } & \multirow[t]{2}{*}{ Year } & \multicolumn{2}{|c|}{ Case-fatality rate $(\mathrm{n}=\mathrm{no}$. of cases) } & \multirow[t]{2}{*}{ Source } \\
\hline & & Pregnant female & Overall & \\
\hline$C A R^{a}$ & 2002 & $20 \%(n=5)$ & $1.8 \%(n=222)$ & {$[34]$} \\
\hline Chad & 2004 & $N A^{b}$ & $3.0 \%(n=989)$ & {$[37]$} \\
\hline Eritrea & 1988-89 & NA & $0 \%(n=423)$ & [44] \\
\hline Ethiopia & 1988-91 & $42.1 \%(n=19)$ & NA & [6] \\
\hline Kenya & 2012 & $12.5 \%(n=72)$ & $2.9 \%(n=339)$ & {$[80]$} \\
\hline Somalia & 1988-9 & $13.8 \%(n=N A)$ & $3.0 \%(n=11,413)$ & [94] \\
\hline South Sudan & $2012-3$ & $10.4 \%(n=211)$ & NA & [99] \\
\hline \multirow[t]{3}{*}{ Sudan } & 2004 & $31.1 \%(n=61)$ & $17.8 \%(n=253)$ & [101] \\
\hline & 2004 & $31.1 \%(n=61)$ & $1.7 \%(n=2,621)$ & {$[100]$} \\
\hline & 2004 & NA & $1.7 \%(n=2,472)$ & {$[37]$} \\
\hline Uganda & 2008 & NA & $1.5 \%(n=9,648)$ & [123] \\
\hline
\end{tabular}

${ }^{\mathrm{a} C A R}$; Central African Republic.

${ }^{\mathrm{b}} \mathrm{NA}$; not available.

and measles signifying that these patients require equal attention. Like HEV infections among pregnant woman in Asia, the clinical prognosis is far worse for pregnant women than for men with fatalities reaching four out of 10 infected pregnant women [6]. The concerns for pregnant woman are further amplified when recognizing that HIV prevalence is high among pregnant women in sub-Saharan Africa [132] and co-infection with HIV and HEV as reported here may increase the risk of fulminant or chronic hepatitis. African men co-infected with HIV and HEV are similarly at risk of complications. While appreciating the hardship from all HEV-associated deaths, maternal deaths are the great tragedy of HEV infection likely causing serious adverse consequences for the health and well-being of surviving family members, especially children.

It has been suggested that many hepatitis outbreaks that occurred before the development of diagnostic assays for any hepatitis virus and enterically transmitted NANB hepatitis outbreaks were likely due to HEV as CFRs in pregnant women in these outbreaks were disproportionately high and attack rates were higher in young adults compared to children or adults [23]. This review supports the prior study showing that outbreaks and sporadic cases by NANB reported in Africa, many of which were not considered in the previous study, also display high CFR in pregnant women and high clinical attack rate among young adults (Tables A1-A3 in the Additional file 1).

We noted several limitations with the existing literature. First, there is no diagnostic "gold standard" for HEV infection and existing studies use different assays that vary in sensitivity and specificity adversely impacting the validity and comparability of reports. Second, studies measure the prevalence of HEV infection in dissimilar subpopulations making it difficult to compare seroprevalence. For example, it is difficult to conclude whether the overall seroprevalence

Table 5 Genotype distribution from African HEVs

\begin{tabular}{|c|c|c|c|c|c|}
\hline Genotype & Country & Year of sampling & Sample & RNA region tested & Source \\
\hline \multirow[t]{10}{*}{1} & $C A R^{a}$ & 2002 & One fecal sample from an outbreak & $N A^{b}$ & [34] \\
\hline & \multirow[t]{2}{*}{ Chad } & 1984 & A patient with hepatitis $E$ & Complete genome & {$[28]$} \\
\hline & & 2004 & Five isolates from an outbreak & $\mathrm{ORF}^{\mathrm{c}} 2\left(363 \mathrm{nt}^{\mathrm{d}}\right)$ & [35] \\
\hline & \multirow[t]{3}{*}{ Egypt } & 1993 & Acute hepatitis patients & ORF1 (location: 55-320) & [46] \\
\hline & & $2006-8$ & Acute hepatitis patients & ORF1 & {$[62]$} \\
\hline & & $2012^{e}$ & Sixteen isolates from acute hepatitis patients & ORF2 (189 nt) & [124] \\
\hline & Namibia & 1983 & Nine isolates from an outbreak in Kavango & ORF2 (296 nt), 3 (188 nt) & [88] \\
\hline & Sudan & 2004 & Twenty three isolates from an outbreak & ORF2 (363 nt) & [35] \\
\hline & \multirow[t]{2}{*}{ Uganda } & 2007 & Internally displaced persons camp & NA & [123] \\
\hline & & 2008 & Twenty four isolates from an outbreak & NA & [119] \\
\hline \multirow[t]{4}{*}{2} & CAR & 2002 & Three fecal samples from an outbreak & NA & [34] \\
\hline & Chad & 2004 & Four isolates from an outbreak & ORF2 (363 nt) & [35] \\
\hline & Namibia & 1995 & Four isolates from NANB outbreak in Rundu & ORF2 (451 nt near 3'-end) & {$[87]$} \\
\hline & Nigeria & $2000^{e}$ & Ten adult acute hepatitis patients & ORF1, 2 (3'-end) & [89] \\
\hline \multirow[t]{3}{*}{3} & Egypt & 2007 & One 9 year-old acute hepatitis patient & ORF1, 2, 2/3 & [48] \\
\hline & Mayotte & 2009 & One French acute hepatitis patient (46 yr old) & ORF2 (288 nt) & {$[82]$} \\
\hline & Madagascar & $2008-9$ & Slaughter house workers & ORF2,3 (1000 nt) & [81] \\
\hline
\end{tabular}

${ }^{a}$ CAR; Central African Republic.

${ }^{\mathrm{b}} \mathrm{NA}$; not available.

'ORF; open reading frame.

${ }^{d}$ nt; nucleotides.

epublication year. 


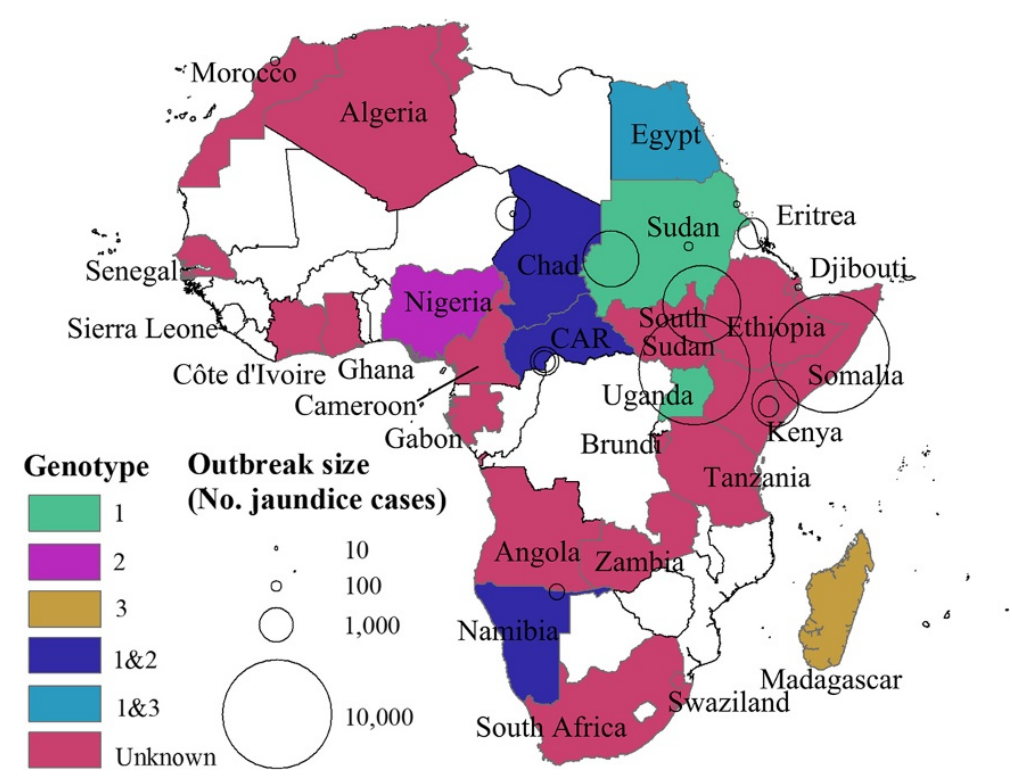

Figure 2 Map of Africa. Colored areas represent countries where HEV is endemic at least for some subpopulations or sporadic HEV cases or outbreaks have been detected. Circles indicate HEV outbreaks with centers and areas indicating the location and outbreak size, respectively. Different colors represent different genotypes. White areas indicate countries where no data is available.

of HEV infection in South Africa is higher than that in Morocco when examining studies that show seroprevalence among South Africans with a mean age of 42 years is $10.7 \%$ [98] and that among younger population in Morocco is 2.2$6.8 \%[84,85]$. Third, studies use different criteria to define acute hepatitis. In a study of Egyptian children, acute hepatitis was defined as the acute injury to the liver, manifested by two fold or more increase in the level of aspartate aminotransferase and alanine aminotransferase [47] whereas in another study, acute hepatitis was defined as the patient whose aminotransferase level was 5 times the normal value [133]. Finally, different surveillance methods may lead to different attack rates being determined. Attack rates are exceptionally difficult to determine in un-enumerated populations, which is likely to be the case in many African nations. The limitations noted above could be corrected in future studies by developing and publishing standardized study methods including case definitions and analytical plans and by development of a generic protocol for outbreak and endemic disease investigations. For diagnosis, an enzyme-linked immunosorbent assay for HEV IgG and IgM (Beijing Wantai Biological Pharmacy Enterprise CO., LTD.) shows high sensitivity and specificity compared to other assays including molecular methods [134].

There are knowledge gaps. Serology studies suggest that many Africans are infected with HEV, but except during outbreaks, symptomatic disease is only sporadic implying that case finding is incomplete or that only a few infected cases progress to clinical disease. Pathogenesis studies are needed. While there are a growing number of published reports on the impact of HEV infection, the overall burden of hepatitis E in Africa remains unclear. For example, two studies from South Asia using verbal autopsies suggest that HEV is responsible for $10 \%$ or more of pregnancyassociated deaths $[135,136]$. The same investigation should also be carried out in multiple sites in Africa. HEV transmission in nations with genotypes 1 and 2 likely occurs from the fecal-oral route. However, the authors in one study on the HEV epidemic in Uganda during 2007-9 claimed that person-to-person transmission played a significant role in the propagation of HEV $[120,137]$. Because of the implications for control measures, this report implies that HEV transmission studies should be carried out. Given the high background rates of HEV infection, the effect of co-infections (e.g., HIV, Hepatitis B) on the severity of disease especially in pregnant women are needed. Potential risk factors for HEV infection such as co-infections or pregnancy need to be clarified. Studies of vertical transmission and blood donor screening should be funded.

As these results suggest that acute hepatitis E is fecalorally transmitted in African countries, the ultimate control of this disease will require increased access to safe water and sanitation and improved personal hygiene. Until these measures are universal, an anti-HEV vaccine is needed. Hecolin $^{\text {Tx }}$ is a safe and effective anti-HEV vaccine for healthy subjects 16 years of age and older exposed to HEV genotype 4. The vaccine is now licensed in China [14]. This vaccine shows promise for outbreak interventions and control of endemic disease but several epidemiological issues need to be addressed before the vaccine is used widely in Africa. The participants in the efficacy trial used for licensing Hecolin $^{\text {Tw }}$ were healthy adults, and there is no safety 
data on persons with chronic liver disease, the immunocompromised, and among children less than 16 years old. While the vaccine has also been found safe in a small number of pregnant women $(n=37)$ inadvertently vaccinated during a large clinical trial [138], there is a necessity for demonstrating safety in well-powered trials of pregnant women as this population should be included in outbreak response because of the high case fatality rate. While vaccine efficacy has been established for genotype 4, there are no studies in patients with genotype 1 or 2 , the prominent strains in Africa. For outbreaks, it is unknown how quickly after the first injection protection will be afforded to those at risk early in the outbreak. There are no published reports on the length of protection. Still, these issues can and should be addressed quickly as there is a potential for this vaccine is be a major component of African HEV control program.

\section{Conclusions}

Extensive data suggest that hepatitis $\mathrm{E}$ is a major contributor to disease and mortality across much of the African continent, with country-level variability, as expected. Still, it is challenging to make comparisons across these populations, given differing methodologies and assays used to determine HEV etiology. Despite its substantial impact on human health, HEV has, even in hyper-endemic South Asia, been neglected in recognition as a major public health problem since its identification. Given the emerging evidence that HEV could be vaccine preventable, we hope this review will shed light on a pathogen of significance across the African continent.

\section{Additional file}

Additional file 1: Table A1. Sporadic hepatitis cases caused by NANB viruses. Table A2. NANB outbreaks in Africa. Table A3. Case-fatality rates (CFRs) by NANB.

\section{Abbreviations}

HEV: Hepatitis E virus; CFR: Case fatality rate; NANB: Non A, non B; HBV: Hepatitis B virus; CAR: Central African Republic; DRC: Democratic Republic of the Congo; ORF: Open reading frame; NT: Nucleotides; NA: Not available.

\section{Competing interests}

The authors declare that they have no competing interests.

\section{Authors' contributions}

TFW outlined the manuscript, oversaw the development, and with J-HK wrote the manuscript. J-HK, UP, and YK searched and J-HK reviewed the literature. All authors reviewed the results, edited the manuscript, and approved the final manuscript.

\section{Acknowledgements}

We thank members at IVI for invaluable comments on the manuscript. This manuscript was edited by the IVI Communications \& Advocacy Unit. The IVI receives funding support from the Bill and Melinda Gates Foundation, and the governments of Korea and Sweden.

\section{Author details}

${ }^{1}$ International Vaccine Institute, SNU Research Park, San 4-8,

Nakseongdae-dong, Gwanak-gu, Seoul 151-919, South Korea. ²Department of Epidemiology, Bloomberg School of Public Health, Johns Hopkins University, 615 N. Wolfe Street, Baltimore, MD 21205, USA.

Received: 15 October 2013 Accepted: 28 May 2014

Published: 5 June 2014

\section{References}

1. Viral hepatitis. [http://apps.who.int/gb/ebwha/pdf_files/WHA63/A63_15-en.pdf]

2. Purcell $\mathrm{RH}$, Emerson SU: Hepatitis E: an emerging awareness of an old disease. J Hepatol 2008, 48:494-503.

3. Teshale EH, Hu DJ: Hepatitis E: epidemiology and prevention. World J Hepatol 2011, 3:285-291.

4. Kamar N, Bendall R, Legrand-Abravanel F, Xia NS, ljaz S, Izopet J, Dalton HR: Hepatitis E. Lancet 2012, 379:2477-2488.

5. Skidmore S: Overview of Hepatitis E virus. Curr Infect Dis Rep 2002, 4:118-123.

6. Tsega E, Krawczynski K, Hansson BG, Nordenfelt E: Hepatitis E virus infection in pregnancy in Ethiopia. Ethiop Med J 1993, 31:173-181.

7. Balayan MS, Andjaparidze AG, Savinskaya SS, Ketiladze ES, Braginsky DM, Savinov AP, Poleschuk VF: Evidence for a virus in non-A, non-B hepatitis transmitted via the fecal-oral route. Intervirology 1983, 20:23-31.

8. Tam AW, Smith MM, Guerra ME, Huang CC, Bradley DW, Fry KE, Reyes GR: Hepatitis E virus (HEV): molecular cloning and sequencing of the full-length viral genome. Virology 1991, 185:120-131.

9. Aggarwal R: Diagnosis of hepatitis E. Nat Rev Gastroenterol Hepatol 2012, 10:24-33.

10. Emerson SU, Purcell RH: Hepatitis E Virus. In Fields Virology. Fifthth edition. Edited by Knipe DM, Howley PM. Philadelphia: Lippincott Williams and Wilkins; 2007:3047-3058.

11. Schlauder GG, Mushahwar IK: Genetic heterogeneity of hepatitis E virus. J Med Virol 2001, 65:282-292.

12. Lu L, Li C, Hagedorn CH: Phylogenetic analysis of global hepatitis E virus sequences: genetic diversity, subtypes and zoonosis. Rev Med Virol 2006, 16:5-36.

13. Purdy MA, Khudyakov YE: The molecular epidemiology of hepatitis E virus infection. Virus Res 2011, 161:31-39.

14. Zhu FC, Zhang J, Zhang XF, Zhou C, Wang ZZ, Huang SJ, Wang H, Yang CL, Jiang HM, Cai JP, Wang YJ, Ai X, Hu YM, Tang Q, Yao X, Yan Q, Xian YL, Wu T, Li YM, Miao J, Ng MH, Shih JW, Xia NS: Efficacy and safety of a recombinant hepatitis $E$ vaccine in healthy adults: a large-scale, randomised, double-blind placebo-controlled, phase 3 trial. Lancet 2010, 376:895-902.

15. Shrestha MP, Scott RM, Joshi DM, Mammen MP Jr, Thapa GB, Thapa N, Myint KS, Fourneau M, Kuschner RA, Shrestha SK, David MP, Seriwatana J, Vaughn DW, Safary A, Endy TP, Innis BL: Safety and efficacy of a recombinant hepatitis E vaccine. N Engl J Med 2007, 356:895-903.

16. Zhang J, Liu CB, Li RC, Li YM, Zheng YJ, Li YP, Luo D, Pan BB, Nong Y, Ge SX, Xiong JH, Shih JW, Ng MH, Xia NS: Randomized-controlled phase II clinical trial of a bacterially expressed recombinant hepatitis $E$ vaccine. Vaccine 2009, 27:1869-1874

17. Proffitt A: First HEV vaccine approved. Nat Biotechnol 2012, 30:300-300.

18. Park SB: Hepatitis E vaccine debuts. Nature 2012, 491:21-22.

19. Viswanathan $R$ : A review of the literature on the epidemiology of infectious hepatitis. Indian J Med Res 1957, 45:145-155.

20. Wong DC, Purcell RH, Sreenivasan MA, Prasad SR, Pavri KM: Epidemic and endemic hepatitis in India: evidence for a non- $A$, non-B hepatitis virus aetiology. Lancet 1980, 2:876-879.

21. Arankalle VA, Chadha MS, Tsarev SA, Emerson SU, Risbud AR, Banerjee K, Purcell RH: Seroepidemiology of water-borne hepatitis in India and evidence for a third enterically-transmitted hepatitis agent. Proc Natl Acad Sci U S A 1994, 91:3428-3432.

22. Rein DB, Stevens GA, Theaker J, Wittenborn JS, Wiersma ST: The global burden of hepatitis E virus genotypes 1 and 2 in 2005. Hepatology 2012, 55:988-997.

23. Teo CG: Fatal outbreaks of jaundice in pregnancy and the epidemic history of hepatitis E. Epidemiol Infect 2012, 140:767-787.

24. Cause-specific mortality, 2008: WHO region. [http://apps.who.int/gho/ data/node.main.887?lang=en] 
25. World Population Prospects, the 2010 Revision. [http://esa.un.org/unpd/ wpp/Excel-Data/population.htm]

26. van Cuyck-Gandre H, Zhang HY, Tsarev SA, Clements NJ, Cohen SJ, Caudill JD, Buisson Y, Coursaget P, Warren RL, Longer CF: Characterization of hepatitis E virus (HEV) from Algeria and Chad by partial genome sequence. J Med Virol 1997, 53:340-347.

27. van Cuyck-Gandre H, Caudill JD, Zhang HY, Longer CF, Molinie C, Roue R, Deloince R, Coursaget P, Mamouth NN, Buisson Y: Short report: polymerase chain reaction detection of hepatitis $E$ virus in north African fecal samples. Am J Trop Med Hyg 1996, 54:134-135.

28. van Cuyck-Gandre $H$, Juge $F$, Roques P: Phylogenetic analysis of the first complete hepatitis E virus (HEV) genome from Africa. FEMS Immunol Med Microbiol 2003, 39:133-139.

29. Traore KA, Rouamba H, Nebie Y, Sanou M, Traore AS, Barro N, Roques P: Seroprevalence of fecal-oral transmitted hepatitis $A$ and $E$ virus antibodies in Burkina Faso. PLoS One 2012, 7:e48125.

30. Aubry P, Niel L, Niyongabo T, Kerguelen S, Larouze B: Seroprevalence of hepatitis $E$ virus in an adult urban population from Burundi. Am J Trop Med Hyg 1997, 57:272-273.

31. Aubry $P$, Larouze $B$, Niyongabo $T$, Niel $L$ : [Markers of hepatitis $C$ and $E$ virus in Burundi (central Africa)]. Bull Soc Pathol Exot 1997, 90:150-152.

32. Feldt T, Sarfo FS, Zoufaly A, Phillips RO, Burchard G, van Lunzen J, Jochum J, Chadwick D, Awasom C, Claussen L, Drosten C, Drexler JF, Eis-Hubinger AM: Hepatitis E virus infections in HIV-infected patients in Ghana and Cameroon. J Clin Virol 2013, 58:18-23.

33. Pawlotsky JM, Belec L, Gresenguet G, Deforges L, Bouvier M, Duval J, Dhumeaux D: High prevalence of hepatitis B, C, and E markers in young sexually active adults from the Central African Republic. J Med Virol 1995, 46:269-272.

34. Escriba JM, Nakoune E, Recio C, Massamba PM, Matsika-Claquin MD, Goumba C, Rose AM, Nicand E, Garcia E, Leklegban C, Koffi B: Hepatitis E, Central African Republic. Emerg Infect Dis 2008, 14:681-683.

35. Nicand E, Armstrong GL, Enouf V, Guthmann JP, Guerin JP, Caron M, Nizou JY, Andraghetti R: Genetic heterogeneity of hepatitis E virus in Darfur, Sudan, and neighboring Chad. J Med Virol 2005, 77:519-521.

36. Coursaget P, Buisson Y, N'Gawara MN, Van Cuyck-Gandre H, Roue R: Role of hepatitis $E$ virus in sporadic cases of acute and fulminant hepatitis in an endemic area (Chad). Am J Trop Med Hyg 1998, 58:330-334.

37. World Health Organization: Hepatitis E: Chad, Sudan. Wkly Epidemiol Rec 2004, 79:321.

38. World Health Organization: Hepatitis E, Chad. Wkly Epidemiol Rec 2004, 79:313.

39. Sarthou JL, Budkowska A, Sharma MD: Characterization of an antigenantibody system associated with epidemic non-A, non-B hepatitis in West Africa and experimental transmission of an infectious agent to primates. Ann Inst Pasteur Virol 1986, 137:225-232.

40. Kaba M, Colson P, Musongela JP, Tshilolo L, Davoust B: Detection of hepatitis $E$ virus of genotype 3 in a farm pig in Kinshasa (Democratic Republic of the Congo). Infect Genet Evol 2010, 10:154-157.

41. Coursaget P, Buisson $Y$, Enogat N, Bercion R, Baudet JM, Delmaire P, Prigent $D$, Desrame J: Outbreak of enterically-transmitted hepatitis due to hepatitis A and hepatitis E viruses. J Hepatol 1998, 28:745-750.

42. Gambel JM, Drabick JJ, Seriwatana J, Innis BL: Seroprevalence of hepatitis E virus among United Nations Mission in Haiti (UNMIH) peacekeepers, 1995. Am J Trop Med Hyg 1998, 58:731-736.

43. Tsega E, Hansson BG, Krawczynski K, Nordenfelt E: Acute sporadic viral hepatitis in Ethiopia: causes, risk factors, and effects on pregnancy. Clin Infect Dis 1992, 14:961-965.

44. Tsega E, Krawczynski K, Hansson BG, Nordenfelt E, Negusse Y, Alemu W, Bahru Y: Outbreak of acute hepatitis E virus infection among military personnel in northern Ethiopia. J Med Virol 1991, 34:232-236.

45. Hyams KC, McCarthy MC, Kaur M, Purdy MA, Bradley DW, Mansour MM, Gray S, Watts DM, Carl M: Acute sporadic hepatitis E in children living in Cairo, Egypt. J Med Virol 1992, 37:274-277.

46. Divizia M, Gabrieli R, Stefanoni ML, Renganathan E, El Ghazzawi E, Kader OA, Gamil F, El Sawaf G, El Sherbini E, Saleh E, Degener AM, Noce A, Zaratti L, Modesti A, Pana A: HAV and HEV infection in hospitalised hepatitis patients in Alexandria, Egypt. Eur J Epidemiol 1999, 15:603-609.

47. El-Sayed Zaki M, El-Deen Zaghloul MH, El Sayed O: Acute sporadic hepatitis $E$ in children: diagnostic relevance of specific immunoglobulin $M$ and immunoglobulin G compared with nested reverse transcriptase PCR. FEMS Immunol Med Microbiol 2006, 48:16-20.
48. Kamel AH, Ali MA, El-Nady HG, Deraz A, Aho S, Pothier P, Belliot G: Presence of enteric hepatitis viruses in the sewage and population of Greater Cairo. Clin Microbiol Infect 2011, 17:1182-1185.

49. Kamel MA, Troonen H, Kapprell HP, el-Ayady A, Miller FD: Seroepidemiology of hepatitis E virus in the Egyptian Nile Delta. J Med Virol 1995, 47:399-403.

50. Amer AF, Zaki SA, Nagati AM, Darwish MA: Hepatitis E antibodies in Egyptian adolescent females: their prevalence and possible relevance. J Egypt Public Health Assoc 1996, 71:273-284.

51. Darwish MA, Faris R, Clemens JD, Rao MR, Edelman R: High seroprevalence of hepatitis $A, B, C$, and $E$ viruses in residents in an Egyptian village in The Nile Delta: a pilot study. Am J Trop Med Hyg 1996, 54:554-558.

52. Abdel Hady SI, El-Din MS, El-Din ME: A high hepatitis E virus (HEV) seroprevalence among unpaid blood donors and haemodialysis patients in Egypt. J Egypt Public Health Assoc 1998, 73:165-179.

53. Abdel Rahman MM, Massoud AM, Kamel MA, Sabry AH, Ahmed GN: Risk of hepatitis "E" virus infection among some schistosomiasis patients in Egypt. J Egypt Soc Parasitol 1995, 25:115-123.

54. Fix AD, Abdel-Hamid M, Purcell RH, Shehata MH, Abdel-Aziz F, Mikhail N, el Sebai H, Nafeh M, Habib M, Arthur RR, Emerson SU, Strickland GT: Prevalence of antibodies to hepatitis $\mathrm{E}$ in two rural Egyptian communities. Am J Trop Med Hyg 2000, 62:519-523.

55. Stoszek SK, Abdel-Hamid M, Saleh DA, El Kafrawy S, Narooz S, Hawash Y, Shebl FM, El Daly M, Said A, Kassem E, Mikhail N, Engle RE, Sayed M, Sharaf S, Fix AD, Emerson SU, Purcell RH, Strickland GT: High prevalence of hepatitis $\mathrm{E}$ antibodies in pregnant Egyptian women. Trans R Soc Trop Med Hyg 2006, 100:95-101.

56. Stoszek SK, Engle RE, Abdel-Hamid M, Mikhail N, Abdel-Aziz F, Medhat A, Fix AD, Emerson SU, Purcell RH, Strickland GT: Hepatitis E antibody seroconversion without disease in highly endemic rural Egyptian communities. Trans $R$ Soc Trop Med Hyg 2006, 100:89-94.

57. Abe K, Li TC, Ding X, Win KM, Shrestha PK, Quang VX, Ngoc TT, Taltavull TC, Smirnov AV, Uchaikin VF, Luengrojanakul P, Gu H, El-Zayadi AR, Prince AM, Kikuchi K, Masaki N, Inui A: International collaborative survey on epidemiology of hepatitis E virus in 11 countries. Southeast Asian J Trop Med Public Health 2006, 37:90-95.

58. Gad YZ, Mousa N, Shams M, Elewa A: Seroprevalence of subclinical HEV infection in asymptomatic, apparently healthy, pregnant women in Dakahlya Governorate, Egypt. Asian J Transfus Sci 2011, 5:136-139.

59. El-Esnawy NA, Gamil MA, El-Wakkad AS: Detection of hepatitis E virus in greater Cairo. Two wastewater treatment plants and its prevalence among workers of these plants. J Egypt Public Health Assoc 1998, 73:597-619.

60. Albatanony MA, El-Shafie MK: Work-Related Health Effects among Wastewater Treatment Plants Workers. Int J Occup Environ Med 2011, 2:237-244.

61. El-Esnawy NA, Al-Herrawy AZ: Seroprevalence of certain hepatitis viruses among Egyptian workers infected with schistosomiasis. J Egypt Public Health Assoc 2000, 75:357-366.

62. Blackard JT, Rouster SD, Nady S, Galal G, Marzuuk N, Rafaat MM, Daef E, El Din SS, Purcell RH, Emerson SU, Sherman KE, Shata MT: Genotypic characterization of symptomatic hepatitis E virus (HEV) infections in Egypt. J Clin Virol 2009, 46:140-144.

63. Eldin SS, Seddik I, Daef EA, Shata MT, Raafat M, Abdel Baky L, Nafeh MA: Risk factors and immune response to hepatitis $E$ viral infection among acute hepatitis patients in Assiut, Egypt. Egypt I Immunol 2010, 17:73-86.

64. Zakaria S, Fouad R, Shaker O, Zaki S, Hashem A, El-Kamary SS, Esmat G: Changing patterns of acute viral hepatitis at a major urban referral center in Egypt. Clin Infect Dis 2007, 44:e30-e36.

65. Aboulata AA, Ahmad MS, Shaban MM, Zayd KM, Abd El-Moktader AM: Prevalence of hepatitis E virus in Egyptian children presented with minor hepatic disorders. Egypt I Immunol 2005, 12:71-76.

66. El Sayed ZM, Othman W: Role of hepatitis E infection in acute on chronic liver failure in Egyptian patients. Liver Int 2011, 31:1001-1005.

67. Meky FA, Stoszek SK, Abdel-Hamid M, Selim S, Abdel-Wahab A, Mikhail N, ElKafrawy S, El-Daly M, Abdel-Aziz F, Sharaf S, Mohamed MK, Engle RE, Emerson SU, Purcell RH, Fix AD, Strickland GT: Active surveillance for acute viral hepatitis in rural villages in the Nile Delta. Clin Infect Dis 2006, 42:628-633.

68. Bassily S, Boctor FN, Farid Z, Fanous A, Yassin MY, Wallace CK: Acute hepatitis non- $A$ non-B in Cairo residents (a preliminary report). Trans $R$ Soc Trop Med Hyg 1983, 77:382-383.

69. Shata MT, Daef EA, Zaki ME, Abdelwahab SF, Marzuuk NM, Sobhy M, Rafaat M, Abdelbaki L, Nafeh MA, Hashem M, El-Kamary SS, Shardell MD, Mikhail NN, Strickland GT, Sherman KE: Protective role of humoral immune responses 
during an outbreak of hepatitis E in Egypt. Trans R Soc Trop Med Hyg 2012, 106:613-618.

70. El-Zimaity DM, Hyams KC, Imam IZ, Watts DM, Bassily S, Naffea EK, Sultan Y, Emara K, Burans J, Purdy MA, et al: Acute sporadic hepatitis E in an Egyptian pediatric population. Am J Trop Med Hyg 1993, 48:372-376.

71. Gomatos PJ, Monier MK, Arthur RR, Rodier GR, El-Zimaity D, Hassan NF Quinti I, El-Sahly AD, Sultan Y, Hyams KC: Sporadic acute hepatitis caused by hepatitis E virus in Egyptian adults. Clin Infect Dis 1996, 23:195-196.

72. Richard-Lenoble D, Traore O, Kombila M, Roingeard P, Dubois F, Goudeau A: Hepatitis B, C, D, and E markers in rural equatorial African villages (Gabon). Am J Trop Med Hyg 1995, 53:338-341.

73. Caron M, Kazanji M: Hepatitis E virus is highly prevalent among pregnant women in Gabon, central Africa, with different patterns between rural and urban areas. Virol J 2008, 5:158.

74. Martinson FE, Marfo W, Degraaf J: Hepatitis E virus seroprevalence in children living in rural Ghana. West Afr J Med 1999, 18:76-79.

75. Adjei AA, Tettey Y, Aviyase JT, Adu-Gyamfi C, Mingle JA, Nartey ET: Unexpected elevated alanine aminotransferase, aspartate aminotransferase levels and hepatitis E virus infection among persons who work with pigs in Accra, Ghana. Virol J 2010, 7:336

76. Meldal BH, Sarkodie F, Owusu-Ofori S, Allain JP: Hepatitis E virus infection in Ghanaian blood donors - the importance of immunoassay selection and confirmation. Vox Sanquinis 2012, 104:30-36.

77. Adjei AA, Aviyase JT, Tettey Y, Adu-Gyamfi C, Mingle JA, Ayeh-Kumi PF, Adiku TK, Gyasi RK: Hepatitis E virus infection among pig handlers in Accra, Ghana. East Afr Med J 2009, 86:359-363.

78. Adjei AA, Tettey Y, Aviyase JT, Adu-Gyamfi C, Obed S, Mingle JA, Ayeh-Kumi PF, Adiku TK: Hepatitis E virus infection is highly prevalent among pregnant women in Accra, Ghana. Virol J 2009, 6:108.

79. Mast EE, Polish LB, Favorov MO, Khudyakova NS, Collins C, Tukei PM, Koptich D, Khudyakov YE, Fields HA, Margolis HS: Hepatitis E Among Refugees in Kenya: Minimal Apparent Person-to-person Transmission, Evidence for Age-dependent Disease Expression, and New Serologic Assays. In Viral Hepatitis and Liver Disease. Edited by Nishioka K, Suzuki H, Mishiro S, Oda T. Japan: Springer; 1994:375-378.

80. Ahmed JA, Moturi E, Spiegel P, Schilperoord M, Burton W, Kassim NH, Mohamed A, Ochieng M, Nderitu L, Navarro-Colorado C, Burke H, Cookson S, Handzel T, Waiboci LW, Montgomery JM, Teshale E, Marano N: Hepatitis E outbreak, Dadaab refugee camp, Kenya, 2012. Emerg Infect Dis 2013, 19:1010-1012.

81. Temmam S, Besnard L, Andriamandimby SF, Foray C, RasamoelinaAndriamanivo H, Heraud JM, Cardinale E, Dellagi K, Pavio N, Pascalis $\mathrm{H}_{\text {, }}$ Porphyre $V$ : High prevalence of hepatitis $E$ in humans and pigs and evidence of genotype-3 virus in swine, Madagascar. Am J Trop Med Hyg 2013, 88:329-338.

82. Epelboin L, Nicand E, Roussin C, Lernout T, Pettinelli ME, Tesse S, Ali R, Aubry P: A sporadic case of genotype $3 f$ acute hepatitis $E$ in Mayotte. Med Mal Infect 2011, 41:392-394.

83. Benjelloun S, Bahbouhi B, Bouchrit N, Cherkaoui L, Hda N, Mahjour J, Benslimane A: Seroepidemiological study of an acute hepatitis $\mathrm{E}$ outbreak in Morocco. Res Virol 1997, 148:279-287.

84. Bernal MC, Leyva A, Garcia F, Galan I, Piedrola G, Heyermann H, Maroto MC: Seroepidemiological study of hepatitis $E$ virus in different population groups. Eur J Clin Microbiol Infect Dis 1995, 14:954-958.

85. Aamoum A, Baghad N, Boutayeb H, Benchemsi N: [Seroprevalence of hepatitis E virus in Casablanca]. Med Mal Infect 2004, 34:491-492.

86. Isaacson M, Frean J, He J, Seriwatana J, Innis BL: An outbreak of hepatitis E in Northern Namibia, 1983. Am J Trop Med Hyg 2000, 62:619-625.

87. Maila HT, Bowyer SM, Swanepoel R: Identification of a new strain of hepatitis E virus from an outbreak in Namibia in 1995. J Gen Virol 2004, 85:89-95.

88. He J, Binn LN, Tsarev SA, Hayes CG, Frean JA, Isaacson M, Innis BL: Molecular characterization of a hepatitis $E$ virus isolate from Namibia. J Biomed Sci 2000, 7:334-338

89. Buisson $Y$, Grandadam M, Nicand $E$, Cheval P, van Cuyck-Gandre $H$, Innis B, Rehel $P$, Coursaget $P$, Teyssou R, Tsarev S: Identification of a novel hepatitis E virus in Nigeria. J Gen Virol 2000, 81:903-909.

90. Ola SO, Odaibo GN, Olaleye OD, Ayoola EA: Hepatitis B and E viral infections among Nigerian healthcare workers. Afr J Med Med Sci 2012, 41:387-391.

91. Adesina OA, Japhet MO, Donbraye E, Kumapayi TE, Kudoro A: Anti hepatitis E virus antibodies in sick and healthy Individuals in Ekiti State, Nigeria. Afr J Microbiol Res 2009, 3:533-536.
92. Crato M, Michel P, Rodier GR, Ka M, Hugard L, Diouf $G$ : Viral markers of acute hepatitis: A, B, C, D, and E in Dakar. October 92 - October 93. Dakar Med 1993, 38:183-185.

93. Pillot J, Lazizi $Y$, Diallo $Y$, Lequenno B: Frequent sporadic hepatitis $E$ in west Africa evidenced by characterization of a virus-associated antigen in the stool. $J$ Hepatol 1992, 15:420-421.

94. Bile K, Isse A, Mohamud O, Allebeck P, Nilsson L, Norder H, Mushahwar IK, Magnius LO: Contrasting roles of rivers and wells as sources of drinking water on attack and fatality rates in a hepatitis E epidemic in Somalia. Am J Trop Med Hyg 1994, 51:466-474.

95. Mushahwar IK, Dawson GJ, Bile KM, Magnius LO: Serological studies of an enterically transmitted non-A, non-B hepatitis in Somalia. J Med Virol 1993, 40:218-221.

96. Burans JP, Sharp T, Wallace M, Longer C, Thornton S, Batchelor R, Clemens $\checkmark$, Hyams KC: Threat of hepatitis E virus infection in Somalia during Operation Restore Hope. Clin Infect Dis 1994, 18:100-102.

97. Grabow WO, Favorov MO, Khudyakova NS, Taylor MB, Fields HA: Hepatitis E seroprevalence in selected individuals in South Africa. J Med Virol 1994, 44:384-388.

98. Tucker TJ, Kirsch RE, Louw SJ, Isaacs S, Kannemeyer J, Robson SC: Hepatitis $E$ in South Africa: evidence for sporadic spread and increased seroprevalence in rural areas. J Med Virol 1996, 50:117-119.

99. Centers for Disease Control and Prevention: Investigation of hepatitis E outbreak among refugees - Upper Nile, South Sudan, 2012-2013. MMWR Morb Mortal Wkly Rep 2013, 62:581-586.

100. Guthmann JP, Klovstad H, Boccia D, Hamid N, Pinoges L, Nizou JY, Tatay M, Diaz F, Moren A, Grais RF, Ciglenecki I, Nicand E, Guerin PJ: A large outbreak of hepatitis E among a displaced population in Darfur, Sudan, 2004: the role of water treatment methods. Clin Infect Dis 2006, 42:1685-1691.

101. Boccia D, Guthmann JP, Klovstad H, Hamid N, Tatay M, Ciglenecki I, Nizou JY, Nicand E, Guerin PJ: High mortality associated with an outbreak of hepatitis E among displaced persons in Darfur, Sudan. Clin Infect Dis 2006, 42:1679-1684.

102. World Health Organization: Hepatitis E, Sudan-update. Wkly Epidemiol Rec 2004, 79:341-342.

103. Mudawi HM, Yousif BA: Fulminant hepatic failure in an African setting: etiology, clinical course, and predictors of mortality. Dig Dis Sci 2007, 52:3266-3269.

104. Rayis DA, Jumaa AM, Gasim Gl, Karsany MS, Adam I: An outbreak of hepatitis E and high maternal mortality at Port Sudan, Eastern Sudan. Pathog Glob Health 2013, 107:66-68.

105. Hyams KC, Hussain MAM, Alarabi MA, Atallah NA, Eltigani A, McCarthy MC: Acute sproradic hepatitis in Sudannese children. J Med Virol 1991, 33:73-76.

106. Ben Halima M, Arrouji Z, Slim A, Lakhoua R, Ben Redjeb S: [Epidemiology of hepatitis E in Tunisia]. Tunis Med 1998, 76:129-131.

107. Hannachi N, Boughammoura L, Marzouk M, Tfifha M, Khlif A, Soussi S, Skouri H, Boukadida J: [Viral infection risk in polytransfused adults: seroprevalence of seven viruses in central Tunisia]. Bull Soc Pathol Exot 2011, 104:220-225.

108. Hannachi N, Hidar S, Harrabi I, Mhalla S, Marzouk M, Ghzel H, Ghannem H, Khairi $\mathrm{H}$, Boukadida J: [Seroprevalence and risk factors of hepatitis $E$ among pregnant women in central Tunisia]. Pathol Biol (Paris) 2011, 59: e115-e118.

109. Houcine N, Jacques R, Salma F, Anne-Gaelle D, Amin S, Mohsen H, Hamadi B, Christophe R, Patrice A, Mahjoub A, Caroline S: Seroprevalence of hepatitis $E$ virus infection in rural and urban populations, Tunisia. Clin Microbiol Infect 2012, 18:E119-E121.

110. Rezig D, Ouneissa R, Mhiri L, Mejri S, Haddad-Boubaker S, Ben Alaya N, Triki $\mathrm{H}$ : [Seroprevalences of hepatitis A and E infections in Tunisia]. Pathol Biol (Paris) 2008, 56:148-153.

111. Safer L, Ben Chaabene N, Melki W, Saffar H: [Epidemiology of viral hepatitis in Tunisia]. Rev Epidemio/ Sante Publique 2006, 54:377-380.

112. Miller WC, Shao JF, Weaver DJ, Shimokura GH, Paul DA, Lallinger GJ: Seroprevalence of viral hepatitis in Tanzanian adults. Trop Med Int Health 1998, 3:757-763.

113. Menendez C, Sanchez-Tapias JM, Kahigwa E, Mshinda H, Costa J, Vidal J, Acosta C, Lopez-Labrador X, Olmedo E, Navia M, Tanner M, Rodes J, Alonso PL: Prevalence and mother-to-infant transmission of hepatitis viruses $B$, C, and E in Southern Tanzania. J Med Virol 1999, 58:215-220.

114. Stark K, Poggensee G, Hohne M, Bienzle U, Kiwelu I, Schreier E: Seroepidemiology of $\Pi$ virus, GBC-C/HGV, and hepatitis viruses $B, C$, 
and E among women in a rural area of Tanzania. J Med Virol 2000, 62:524-530.

115. Jacobs C, Chiluba C, Phiri C, Lisulo MM, Chomba M, Hill PC, ljaz S, Kelly P: Seroepidemiology of Hepatitis E Virus Infection in an Urban Population in Zambia: Strong Association With HIV and Environmental Enteropathy. $J$ Infect Dis 2014, 209:652-657.

116. El-Esnawy NA: Examination for hepatitis E virus in wastewater treatment plants and workers by nested RT-PCR and ELISA. J Egypt Public Health Assoc 2000, 75:219-231.

117. Miller FD: High seroprevalence of hepatitis $A, B, C$, and $E$ virus in an Egyptian village in the Nile Delta. Am J Trop Med Hyg 1997, 57:251.

118. Hyams KC, Purdy MA, Kaur M, McCarthy MC, Hussain MA, el-Tigani A, Krawczynski K, Bradley DW, Carl M: Acute sporadic hepatitis E in Sudanese children: analysis based on a new western blot assay. J Infect Dis 1992 165:1001-1005.

119. Teshale EH, Howard CM, Grytdal SP, Handzel TR, Barry V, Kamili S, Drobeniuc J, Okware S, Downing R, Tappero JW, Bakamutumaho B, Teo CG, Ward JW, Holmberg SD, Hu DJ: Hepatitis E epidemic, Uganda. Emerg Infect Dis 2010, 16:126-129.

120. Teshale EH, Grytdal SP, Howard C, Barry V, Kamili S, Drobeniuc J, Hill VR, Okware S, Hu DJ, Holmberg SD: Evidence of person-to-person transmission of hepatitis E virus during a large outbreak in Northern Uganda. Clin Infect Dis 2010, 50:1006-1010.

121. Goumba Al, Konamna X, Komas NP: Clinical and epidemiological aspects of a hepatitis E outbreak in Bangui, Central African Republic. BMC Infect Dis 2011, 11:93.

122. McCarthy MC, He J, Hyams KC, el-Tigani A, Khalid IO, Carl M: Acute hepatitis E infection during the 1988 floods in Khartoum, Sudan. Trans R Soc Trop Med Hyg 1994, 88:177.

123. Howard CM, Handzel T, Hill VR, Grytdal SP, Blanton C, Kamili S, Drobeniuc J, Hu D, Teshale E: Novel risk factors associated with hepatitis E virus infection in a large outbreak in northern Uganda: results from a case-control study and environmental analysis. Am J Trop Med Hyg 2010, 83:1170-1173

124. Delarocque-Astagneau E, Abravanel F, Moshen A, Le Fouler L, Gad RR, El-Daly M, Ibrahim EM, El-Aidy S, Lashin T, El-Hoseiny M, Izopet J, Mohamed MK, Fontanet A, Abdel Hamid M: Epidemiological and virological characteristics of symptomatic acute hepatitis E in Greater Cairo, Egypt. Clin Microbiol Infect 2012, 18:982-988.

125. World Health Organization: Hepatitis E, Fact Sheet No 280. 2013.

126. Boxall E, Herborn A, Kochethu G, Pratt G, Adams D, ljaz S, Teo C-G: Transfusiontransmitted hepatitis E in a "nonhyperendemic" country. Transfus Med 2006, 16:79-83.

127. Matsubayashi K, Kang J-H, Sakata H, Kazuaki Takahashi K, Shindo M, Kato M, Sato S, Kato T, Nishimori H, Tsuji K, Maguchi H, Yoshida J-i, Maekubo H, Mishiro S, Ikeda H: A case of transfusion-transmitted hepatitis $\mathrm{E}$ caused by blood from a donor infected with hepatitis $\mathrm{E}$ virus via zoonotic food-borne route. Transfusion 2008, 48:1368-1375.

128. El-Sayed Zaki M, Abd El Aal A, Badawy A, El-Deeb DR, El-Kheir NYA: Clinicolaboratory study of mother-to-neonate transmission of hepatitis $E$ virus in Egypt. Am J Clin Path 2013, 140:721-726.

129. Zaki Mel S, Salama OS, Mansour FA, Hossein S: Hepatitis E virus coinfection with hepatotropic viruses in Egyptian children. J Microbiol Immunol Infect 2008, 41:254-258

130. Caron M, Bouscaillou J, Kazanji M: Acute risk for hepatitis E virus infection among HIV-1-positive pregnant women in central Africa. Virol J 2012, 9:254

131. Kmush B, Wierzba T, Krain L, Nelson K, Labrique AB: Epidemiology of hepatitis $\mathrm{E}$ in low- and middle-income countries of Asia and Africa. Semin Liver Dis 2013, 33:15-29.

132. UNAIDS: Global report: UNAIDS report on the global AIDS epidemic 2010. In Book Global report: UNAIDS report on the global AIDS epidemic 2010. City: UNAIDS Geneva; 2010.

133. Bassily S, Hyams KC, el Ghorab NM, Ansari AA, Fanous AS: Acute sporadic hepatitis in adults living in Cairo, Egypt. Am J Trop Med Hyg 1986, 35:1040-1044

134. Bendall R, Ellis V, ljaz S, Ali R, Dalton H: A comparison of two commercially available anti-HEV IgG kits and a re-evaluation of anti-HEV IgG seroprevalence data in developed countries. J Med Virol 2010, 82:799-805.

135. Labrique AB, Sikder SS, Krain L, West KP Jr, Christian P, Rashid M, Nelson KE: Hepatitis $E$, a vaccine-preventable cause of maternal deaths. Emerg Infect Dis 2012, 18:1401-1404.
136. Gurley ES, Halder AK, Streatfield PK, Sazzad HM, Huda TM, Hossain MJ, Luby SP: Estimating the burden of maternal and neonatal deaths associated with jaundice in Bangladesh: possible role of hepatitis $\mathrm{E}$ infection. Am J Public Health 2012, 102:2248-2254.

137. Teshale E, Hu DJ, Holmberg SD: Reply to nishiura. Clin Infect Dis 2010, 51:118-119.

138. Wu T, Zhu FC, Huang SJ, Zhang XF, Wang ZZ, Zhang J, Xia NS: Safety of the hepatitis $E$ vaccine for pregnant women: a preliminary analysis. Hepatology 2012, 55:2038.

doi:10.1186/1471-2334-14-308

Cite this article as: Kim et al: A systematic review of the epidemiology of hepatitis E virus in Africa. BMC Infectious Diseases 2014 14:308.

\section{Submit your next manuscript to BioMed Central and take full advantage of:}

- Convenient online submission

- Thorough peer review

- No space constraints or color figure charges

- Immediate publication on acceptance

- Inclusion in PubMed, CAS, Scopus and Google Scholar

- Research which is freely available for redistribution

Submit your manuscript at www.biomedcentral.com/submit
C Biomed Central 